\title{
Interspecific variation in the elemental and stable isotope content of seagrasses in South Florida
}

\author{
Justin E. Campbell ${ }^{1, *}$, James W. Fourqurean ${ }^{1,2}$ \\ ${ }^{1}$ Department of Biological Sciences, Florida International University, Marine Sciences Program, 3000 NE 151 Street, \\ North Miami, Florida 33181, USA \\ ${ }^{2}$ Center for Tropical Plant Conservation, Fairchild Tropical Botanic Garden, 11935 Old Cutler Road, Coral Gables, \\ Miami, Florida 33156, USA
}

\begin{abstract}
The elemental $\left(C, N\right.$, and P) and isotope $\left(\delta^{13} C, \delta^{15} N\right)$ content of leaves of the seagrasses Thalassia testudinum, Halodule wrightii, and Syringodium filiforme were measured across a $10000 \mathrm{~km}^{2}$ survey of the seagrass communities of South Florida, USA, in 1999 and 2000. Trends at local and broad spatial scales were compared to examine interspecific variation in the seagrass characteristics often used as ecological indicators. The elemental and stable isotope contents of all species were variable and demonstrated marked interspecific variation. At broad spatial scales, mean N:P ratios were lowest for $T$. testudinum $(36.5 \pm 1.1)$ and $S$. filiforme $(38.9 \pm 1.3)$, and highest for $H$. wrightii $(44.1 \pm 1.8)$. Stable carbon isotope ratios $\left(\delta^{13} \mathrm{C}\right)$ were highest for $S$. filiforme $(-6.2 \pm 0.2 \%)$, intermediate for $T$. testudinum $(-8.6 \pm 0.2 \%)$, and lowest for $H$. wrightii $(-10.6 \pm 0.3 \%)$. Stable nitrogen isotopes $\left(\delta^{15} \mathrm{~N}\right)$ were heaviest for $T$. testudinum $(2.0 \pm 0.1 \%)$, and lightest for $H$. wrightii $(1.0 \pm$ $0.3 \%$ ) and $S$. filiforme $\left(1.6 \pm 0.2 \%\right.$ ). Site depth was negatively correlated to $\delta^{13} \mathrm{C}$ for all species, while $\delta^{15} \mathrm{~N}$ was positively correlated to depth for $H$. wrightii and $S$. filiforme. Similar trends were observed in local comparisons, suggesting that taxon-specific physiological/ecological properties strongly control interspecific variation in elemental and stable isotope content. Temporal trends in $\delta^{13} \mathrm{C}$ were measured, and revealed that interspecific variation was displayed throughout the year. This work documents interspecific variation in the nutrient dynamics of 3 common seagrasses in South Florida, indicating that interpretation of elemental and stable isotope values needs to be species specific.
\end{abstract}

KEY WORDS: Seagrass - Elemental content $\cdot$ Stable isotopes · Interspecific variation $\cdot$ Carbon acquisition

Resale or republication not permitted without written consent of the publisher

\section{INTRODUCTION}

The elemental and isotope content of plant biomass can be used to characterize both the nutritional status and environmental conditions of macrophyte communities (McMillan et al. 1980, Atkinson \& Smith 1983, Farquhar et al. 1989, Duarte 1992, Fourqurean et al. 2005, 2007). These plant parameters, while reflecting the local availabilities of essential resources (nitrogen, phosphorus, carbon, and light), can additionally reflect interspecific variation and the manner in which species interact with local resources. Taxonomic differences in growth rates, life-history strategies, physiology, and morphology have the ability to influence resultant nitrogen:phosphorus (N:P) ratios and the stable isotope content of plant material (Farquhar et al. 1989, Dawson et al. 2002, Agren 2004). While landscape patterns in elemental and isotope content of submerged plants may be driven by large-scale spatial variations in the stable isotope composition of nutrient pools and the availabilities of nutrients and light, localized interspecific differences have been detected (Fourqurean et al. 2007), and may be attributed to physiological differences among sympatric plant species. Prior to using variations in the N:P ratios and stable isotope compositions of benthic plants for inferring ecosystem processes, it is important to understand the factors that drive these variations at all spatial scales, and how taxonomic differences can be reflected within these parameters. 
The N:P ratio of plant material is related to the availability of these elements in the environment relative to plant demand (Duarte 1990). Over landscape scales, spatial gradients in $\mathrm{N}$ or $\mathrm{P}$ availability are reflected by spatial patterns in plant nutrient content, as shown for seagrasses growing in coastal marine habitats (Fourqurean et al. 1992a, 2005, Fourqurean \& Zieman 2002). Nutrient addition experiments support the close link between environmental availabilities and tissue nutrient content, particularly in locations where ambient elemental concentrations are low (Duarte 1990, Ferdie \& Fourqurean 2004, Armitage et al. 2005). Other environmental factors can also influence the nutrient content of plant material. For example, increased light availability has been found to decrease the nutrient content of seagrass leaves because of enhanced growth rates leading to the depletion of nutrient sources (Abal et al. 1994). Thus, it has been widely documented that resource availability strongly controls intraspecific variation in the elemental ratios of benthic macrophytes. However, variation seen between plant species may be driven by factors other than environmental conditions, suggesting that ecological/physiological differences may drive interspecific variation at any particular location. While singlespecies comparisons have been used across a broad range of seagrasses over large spatial scales, localized interspecific comparisons may provide important cues about the ecological differences occurring between sympatric species (Fourqurean et al. 2007).

The stable isotope content of plant material has provided a powerful tool for the study and assessment of ecological processes. In addition to identifying nutrient sources and processing within ecosystems (Dawson et al. 2002), stable isotopes have aided in food web analysis and the study of energy flow among trophic levels (Peterson \& Fry 1987). However, the factors regulating the stable isotope content of primary producers are complex and require detailed knowledge of spatial, temporal, and taxonomic variation. For example, the stable carbon isotope content of seagrass material is predominantly controlled by the environmental factors of carbon source, irradiance, and temperature (Durako \& Hall 1992, Abal et al. 1994, Grice et al. 1996, Hemminga \& Mateo 1996). Spatial and temporal variation in these factors have been found to influence the carbon isotope content of seagrass species across landscape scales (Fourqurean et al. 1997, 2005), highlighting the importance of documenting background variation when applied to food web studies. Numerous studies have detailed the effect of environmental conditions on intraspecific variation in stable isotope parameters. However, interspecific divergence, particularly among sympatric seagrasses, has received less attention and may be attributable to physiological/eco- logical distinctions between species. Stable isotope comparisons between co-occurring species may reveal important cues pertaining to how species process local resources.

Seagrasses fractionate the available pool of inorganic carbon based upon the degree of carbon demand relative to the degree of carbon supply. For a given carbon supply, plants grown under high light conditions display increased photosynthetic rates and increased carbon demand, resulting in reduced discrimination against ${ }^{13} \mathrm{C}$ and heavier isotope signatures (Cooper \& DeNiro 1989, Durako \& Hall 1992). Similarly, for a given light level, experiments have found enriched carbon isotope signatures $\left(\delta^{13} \mathrm{C}\right)$ with decreases in carbon supply (Durako \& Sackett 1993). These relationships provide environmental information pertaining to the light and inorganic carbon status of plant material. However, interspecific variation in the mechanisms by which plants process carbon can additionally affect $\delta^{13} \mathrm{C}$ values (Farquhar et al. 1989); thus individual plant physiology may contribute to overall variation in stable carbon isotope values. Utilization of bicarbonate (which is isotopically distinct from $\mathrm{CO}_{2}$ ) may influence $\delta^{13} \mathrm{C}$ ratios (Hemminga \& Mateo 1996), and may further contribute to variation in isotope values. Bicarbonate use is dependent upon specific seagrass physiology (Invers et al. 1999); thus interspecific differences in stable isotope values may be attributed to the varied physiologies associated with $\mathrm{HCO}_{3}{ }^{-}$uptake. Systematic differences in the $\delta^{13} \mathrm{C}$ ratios of leaves of co-occurring seagrass species, as documented between the Mediterranean species Posidonia oceanica and Cymodocea nodosa (Fourqurean et al. 2007), would suggest fundamental differences in the way that species interact with the available dissolved inorganic carbon (DIC) pool.

Seagrass stable nitrogen content additionally provides important information pertaining to the identity of the sources of dissolved inorganic nitrogen (DIN), and the various processes that serve to fractionate the available nutrient pool. For example, as bacterial processing (nitrification, denitrification, and nitrogen fixation) alters the ratio of ${ }^{15} \mathrm{~N}:{ }^{14} \mathrm{~N}$ in the DIN pool, the macrophytic composition of stable nitrogen isotopes is influenced, and thus can be used to infer degrees of nitrogen cycling (Peterson \& Fry 1987, Dawson et al. 2002). Due to this microbial processing, sewagederived nutrient inputs are isotopically heavy and can be used to detect possible anthropogenic contributions to the DIN pool.

Similar to carbon isotope discrimination, seagrasses can fractionate the source pool of DIN upon plant uptake (Fourqurean et al. 2005). The degree of nitrogen fractionation depends upon the size of the DIN pool relative to plant demand (Fourqurean et al. 2005). 
Seasonal fluctuations in the $\delta^{15} \mathrm{~N}$ value of seagrass tissues have been detected and have been attributed to changes in both the isotope signature of the source pool and the degree of plant fractionation as a response to seasonal productivities (Fourqurean et al. 2005). However, altered DIN fractionation between multiple species has yet to be documented.

In this paper, we document interspecific divergence in the elemental and stable isotope content of 3 seagrass species in South Florida, and explore environmental correlates of these variations across both local and broad spatial scales. Our aim was to better characterize the sources of variation in elemental and isotope ratios of plants often used as environmental indicators, and to highlight the role that ecological/physiological characteristics play in determining species-specific values. Seagrass properties (N:P, limitation index, $\delta^{13} \mathrm{C}$, and $\delta^{15} \mathrm{~N}$ ) were compared across 136 sites in South Florida, representing a $10000 \mathrm{~km}^{2}$ survey area of the seagrass beds in the Florida Keys National Marine Sanctuary (FKNMS). We were particularly interested in documenting interspecific variation in the properties of seagrasses co-occurring under similar environmental conditions within a given site. We hypothesized that the varied life history strategies of benthic macrophytes would be reflected in plant elemental content, with fast-growing, early successional species displaying N:P ratios farther removed from ideal values as compared to slow-growing species from the same site. We additionally hypothesized that species-specific differences in carbon uptake strategies and plant physiologies have the ability to strongly regulate stable isotope parameters. Lastly, we hypothesized that fast-growing, early successional species may exhibit larger seasonal varia- tion in stable isotope values as a result of increased growth rates and elevated carbon and nitrogen demand. Interspecific comparisons at both local (within site) and broad (among all sites) scales allowed us to examine the spatial extent to which taxonomic variation is important, and its effect on the isotope and elemental composition of benthic plants.

\section{MATERIALS AND METHODS}

The FKNMS, a shallow-water marine ecosystem located at the southern tip of the Florida peninsula, comprises seagrass beds, coral reefs, and mangrove communities (Fig. 1). Seagrass communities in the FKNMS are primarily composed of Thalassia testudinum, Halodule wrightii, and Syringodium filiforme. During the summer months of 1999, 80 sites were randomly selected across the FKNMS and were surveyed for seagrass abundance, nutrient content, and isotope composition. A repeat survey, which only quantified seagrass abundance and nutrient content, was conducted during the summer of 2000 at 56 different randomly generated sites. Seasonal variation in seagrass isotope content was additionally assessed through a separate series of quarterly surveys conducted during 1999 and 2000. Within each year, a network of 30 permanent monitoring stations was sampled 4 times (see Fourqurean et al. 2001 for further description). The elemental and isotope composition of $T$. testudinum has been previously described for this region (Fourqurean et al. 2005). To examine interspecific variation, our current study incorporated a portion of those data on the elemental and isotope content of T. tes-

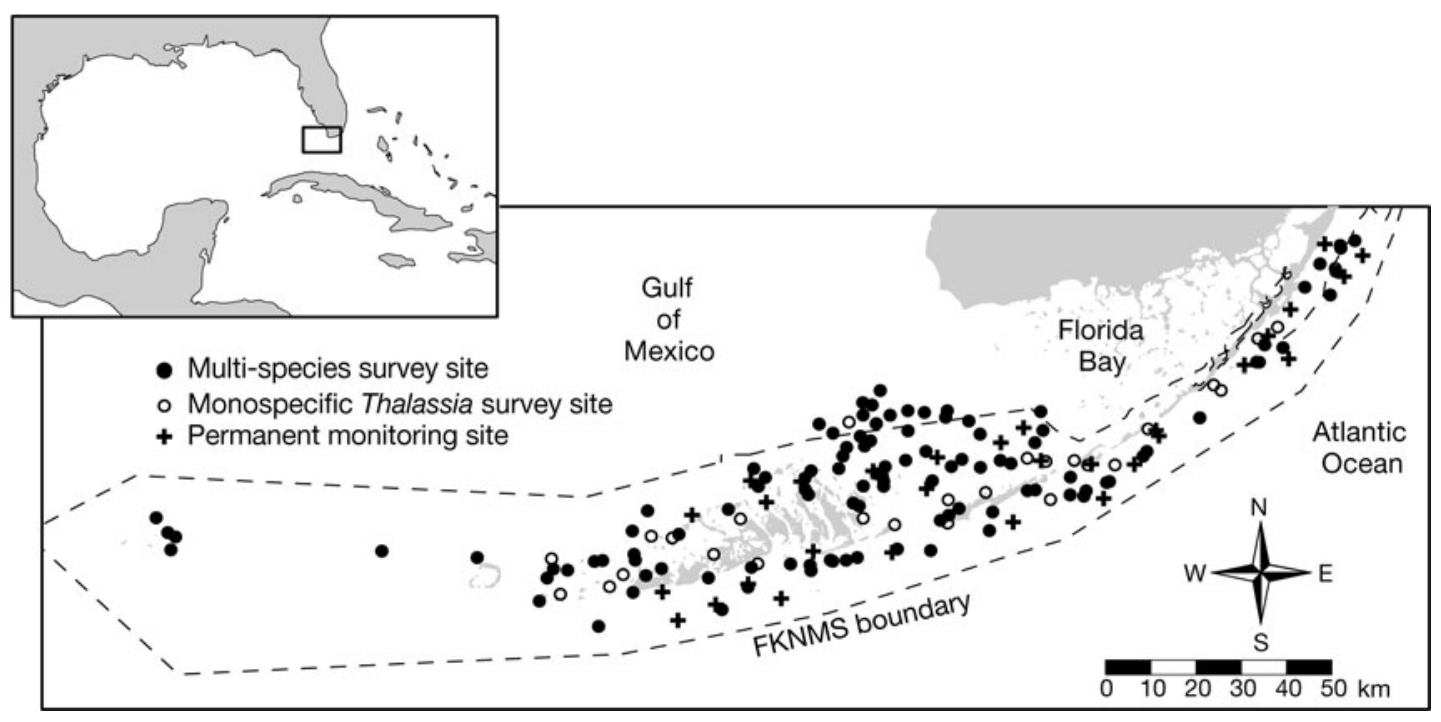

Fig. 1. Study area showing locations of both survey sites and permanent monitoring sites in and near the Florida Keys National Marine Sanctuary (FKNMS). Survey sites were designated as either single- or multi-species seagrass beds 
tudinum, with new data for the other 2 seagrass species (S. filiforme and $H$. wrightii) common in South Florida.

From the selected random sites, 3 separate comparative analyses were conducted that spanned various spatial and seasonal scales. One analysis included all data from the 1999 (80 sites) and 2000 (56 sites) surveys, representing comparisons within the summer season over large spatial scales. Both monospecific $(22 \%)$ and mixed-species $(78 \%)$ seagrass beds were included. A second analysis included data from the 1999 and 2000 summer surveys; however, monospecific sites were excluded, and thus interspecific comparisons were solely conducted within multi-species sites where seagrasses co-occurred under similar environmental conditions. Each multi-species site contained 2 or more seagrass species growing adjacently (<50 m apart), under similar light and depth regimes. Multi-species sites were grouped according to pairwise interspecific comparisons: Thalassia testudinum/ Halodule wrightii (65 sites), H. wrightii/Syringodium filiforme (38 sites), and $T$. testudinum/S. filiforme ( 75 sites). The third analysis similarly conducted withinsite interspecific comparisons, but only used data from the 30 permanent monitoring sites, allowing for comparisons of intra-annual variability between species pairs. Within this network, the number of sites for interspecific comparison varied depending upon season; T. testudinum/H. wrightii (4 to 7 sites), H. wrightii/ S.filiforme (5 to 8 sites), T. testudinum/S. filiforme (19 to 22 sites).

For all surveys, at each sampling site, short shoots of each seagrass species present were haphazardly collected along a $50 \mathrm{~m}$ transect. When available, 6 shoots of Thalassia testudinum, 30 shoots of Syringodium filiforme, and 40 shoots of Halodule wrightii were harvested, placed on ice, and transported back to the laboratory. The less robust seagrass species required higher collection amounts to ensure enough biomass was available for all elemental and isotope analyses. Seagrass leaves were separated according to species, cleaned of epiphytes through gentle scraping with a razor blade, and cut from their respective short shoots. Leaves were then dried to a constant weight at $80^{\circ} \mathrm{C}$, ground to a fine powder with a mortar and pestle, and analyzed in duplicate for $\mathrm{C}$ and $\mathrm{N}$ content using a $\mathrm{CHN}$ analyzer (Fourqurean et al. 2005). Phosphorus content was determined through dry oxidation and acid hydrolysis extraction followed by a colorimetric analysis (Fourqurean et al. 1992a). Elemental ratios were calculated on a mole:mole basis.

All isotope analyses were conducted using standard elemental analyzer isotope ratio mass spectrometer procedures. The elemental analyzer was used to combust all organic material and subsequently reduce the formed gasses into $\mathrm{N}_{2}$ and $\mathrm{CO}_{2}$, which were measured on a Finnigan MAT Delta C IRMS in a continuous flow mode. The samples' isotopic ratios (R) are reported in the standard delta notation $(\delta)$ :

$$
\delta(\%)=\left[\left(\mathrm{R}_{\text {sample }} / \mathrm{R}_{\text {standard }}\right)-1\right] \times 1000
$$

These results are presented with respect to the international standards of atmospheric nitrogen $\left(\mathrm{N}_{2}\right)$ and Vienna Pee Dee belemnite (V-PDB) for carbon. Analytical reproducibility of the reported $\delta$ values, based on sample replicates, was better than $\pm 0.08 \%$ for carbon and $\pm 0.2 \%$ for nitrogen. Care was taken to remove all visible carbonate material from the surface of the leaves. As a test of the efficacy of our cleaning, we acidified a subset of seagrass samples with the most enriched $\delta^{13} \mathrm{C}$ values to drive off any remaining carbonate material, and then determined the $\delta^{13} \mathrm{C}$ of this decalcified material. The differences in $\delta^{13} \mathrm{C}$ between acidified and unacidified samples were small $(<0.3 \%$ on average).

The distributions of all seagrass elemental and isotope parameters were checked for normality using the Kolmogorov-Smirov test $(\alpha=0.05)$. Standard linear regression was used to test the strength of the relationship between stable isotope variables $\left(\delta^{13} \mathrm{C}, \delta^{15} \mathrm{~N}\right)$ and site depth. Relationships among elemental and isotope ratios were additionally assessed for all species, across all sites sampled in 1999, using non-parametric correlations (Spearman's $\rho$ ). Interspecific sanctuary-wide species-specific differences in seagrass $\mathrm{N}: \mathrm{P}$ ratios and isotope values were assessed using a single-factor analysis of variance (ANOVA). Upon detecting significance, post hoc analysis was conducted using either a Tukey's HSD for equal variances, or a Dunnett's T3 test for unequal variances (significance $\mathrm{p}<0.05$ ). In addition to testing $\mathrm{N}: \mathrm{P}$ ratios, a Limitation Index $(\mathrm{LI}=\mid 30-\mathrm{N}: \mathrm{Pl})$ was calculated to quantify the degree of divergence from the ideal ca. 30:1 'Seagrass Redfield Ratio' identified by Atkinson \& Smith (1983) and Duarte (1990). Larger LI values indicate greater degrees of nutrient limitation. Such a calculation is necessary because across the landscape of the FKNMS, there are both $\mathrm{N}$ - and Plimited regions (Fourqurean et al. 2005).

To conduct within-site interspecific comparisons, differences in N:P ratios, LI, $\delta^{13} \mathrm{C}$, and $\delta^{15} \mathrm{~N}$ were tested with a pairwise Student's $t$-test, with significance at $\mathrm{p}$ $<0.05$. To describe temporal variation in seagrass isotope content for species that co-occurred at the 30 permanent stations, we fit a sine model of the form $y=$ mean $+\alpha[\sin ($ time $+\Phi)]$, where $\alpha$ is the amplitude of a sine wave, and $\Phi$ is a phase angle (we used time values in radians for both time and $\Phi$, where $2 \pi$ radians = $365 \mathrm{~d}$ ), to a seasonal time series using an iterative nonlinear curve-fitting regression. Confidence intervals 
(95\%) of model parameters were compared to test for significant differences in seasonal variation. We were interested in using the non-linear regression as a means of testing interspecific divergence in the mean and amplitude of seasonal seagrass $\delta^{13} \mathrm{C}$ variation.

\section{RESULTS}

\section{Interspecific variation at broad scales across the FKNMS}

In 1999, Thalassia testudinum occurred at 78 of the randomly selected sites (98\%), while Halodule wrightii and Syringodium filiforme occurred at 31 sites (39\%) and 37 sites (46\%), respectively. In 2000, T. testudinum occurred at 56 sites (100\%), while $H$. wrightii and S. filiforme occurred at 39 sites $(70 \%)$ and 40 sites $(71 \%)$, respectively. Nitrogen, phosphorus, and carbon content varied within each species, across all sanctuary sites in both years (Table 1); however, they did not vary significantly between years. In both years, coefficients of variation show that leaf phosphorus content $(\mathrm{CV}=$ 0.28-0.37) displayed greater variation in all species compared to nitrogen $(\mathrm{CV}=0.15-0.25)$ and carbon content $(\mathrm{CV}=0.06-0.12)$. The $\mathrm{N}: \mathrm{P}$ frequency distribution for $T$. testudinum was slightly skewed towards higher values (Fig. 2). Comparatively, H. wrightii displayed a normal distribution with the highest mean $\mathrm{N}: \mathrm{P}$ ratios $(44.1 \pm 1.8)$, which were reflected in the highest mean LI of all species (15.3 \pm 1.7, Fig. 3, Table 1). Syringodium filiforme displayed an intermediate N:P ratio of $38.9 \pm 1.3$, which was normally distributed, and an average LI of $10.9 \pm 1.1$. Thalassia testudinum displayed the lowest mean N:P ratio $(36.5 \pm$ 1.1), and the lowest mean LI $(9.6 \pm 0.9)$ of the species. Mean $T$. testudinum N:P ratio and LI were significantly lower than those of Halodule wrightii, yet similar to $S$. filiforme (Table 1). Mean $H$. wrightii N:P ratio and LI were similar to $S$. filiforme (ANOVA, $F=7.89, \mathrm{p}=0.07$; ANOVA, $F=6.25, \mathrm{p}=0.09$ ).

Halodule wrightii displayed the lowest $\delta^{13} \mathrm{C}$ values of all species, with a mean of $-10.6 \pm 0.3 \%$, a range of -13.2 to $-7.8 \%$, and a normal distribution (Fig. 4). $H$.

Table 1. Thalassia testudinum, Halodule wrightii, and Syringodium filiforme. Elemental and stable isotope composition of seagrass leaves collected across the FKNMS in 1999 and 2000. Superscripts on means within a column identify significantly different groups (post hoc tests, $\mathrm{p}<0.05$ ). LI: Limitation Index

\begin{tabular}{|c|c|c|c|c|c|c|c|c|c|}
\hline & $\delta^{15} \mathrm{~N}$ & $\delta^{13} \mathrm{C}$ & $\begin{array}{l}\% \mathrm{C}(\% \\
\text { dry wt) }\end{array}$ & $\begin{array}{l}\% \mathrm{~N}(\% \\
\text { dry wt) }\end{array}$ & $\begin{array}{l}\% \mathrm{P}(\% \\
\text { dry wt) }\end{array}$ & $C: N$ & $\mathrm{C}: \mathrm{P}$ & $\mathrm{N}: \mathrm{P}$ & LI \\
\hline \multicolumn{10}{|l|}{ Thalassia testudinum } \\
\hline Mean & $2.0^{\mathrm{a}}$ & $-8.6^{\mathrm{a}}$ & $39.2^{\mathrm{a}}$ & $1.9^{\mathrm{a}}$ & $0.13^{\mathrm{a}}$ & $24.1^{\mathrm{a}}$ & $870.8^{\mathrm{a}}$ & $36.5^{\mathrm{a}}$ & $9.6^{\mathrm{a}}$ \\
\hline $\mathrm{n}$ & 78 & 78 & 134 & 134 & 134 & 134 & 134 & 134 & 134 \\
\hline $\mathrm{SE}$ & 0.15 & 0.20 & 0.20 & 0.02 & 0.00 & 0.31 & 26.28 & 1.07 & 0.88 \\
\hline $\mathrm{CV}$ & 0.70 & 0.20 & 0.06 & 0.15 & 0.28 & 0.15 & 0.35 & 0.34 & 1.07 \\
\hline Median & 1.8 & -8.3 & 39.6 & 1.9 & 0.13 & 24.0 & 783.7 & 34.4 & 6.2 \\
\hline Minimum & -2.2 & -13.0 & 31.1 & 1.4 & 0.06 & 17.1 & 500.3 & 17.1 & 0.2 \\
\hline Maximum & 5.4 & -5.3 & 43.2 & 2.6 & 0.22 & 33.9 & 1902.3 & 76.5 & 46.5 \\
\hline \multicolumn{10}{|l|}{ Halodule wrightii } \\
\hline Mean & $1.0^{\mathrm{b}}$ & $-10.6^{b}$ & $43.4^{\mathrm{b}}$ & $2.3^{\mathrm{b}}$ & $0.13^{\mathrm{a}}$ & $22.7^{\mathrm{a}}$ & $1014.1^{\mathrm{b}}$ & $44.1^{\mathrm{b}}$ & $15.3^{b}$ \\
\hline $\mathrm{n}$ & 31 & 31 & 70 & 70 & 70 & 70 & 70 & 70 & 70 \\
\hline SE & 0.29 & 0.28 & 0.27 & 0.05 & 0.01 & 0.44 & 51.76 & 1.82 & 1.67 \\
\hline $\mathrm{CV}$ & 1.70 & 0.15 & 0.05 & 0.17 & 0.37 & 0.16 & 0.43 & 0.35 & 0.91 \\
\hline Median & 0.9 & -10.8 & 43.9 & 2.26 & 0.12 & 22.5 & 890.9 & 39.7 & 9.7 \\
\hline Minimum & -3.5 & -13.2 & 35.0 & 1.48 & 0.05 & 16.7 & 472.3 & 23.7 & 0.3 \\
\hline Maximum & 4.0 & -7.8 & 46.3 & 3.18 & 0.25 & 33.9 & 2572.2 & 94.9 & 64.9 \\
\hline \multicolumn{10}{|l|}{ Syringodium filiforme } \\
\hline Mean & $1.6^{\mathrm{ab}}$ & $-6.2^{\mathrm{c}}$ & $38.9^{\mathrm{a}}$ & $2.1^{\mathrm{c}}$ & $0.13^{\mathrm{a}}$ & $22.8^{\mathrm{a}}$ & $866.0^{\mathrm{a}}$ & $38.9^{\mathrm{ab}}$ & $10.9^{\mathrm{ab}}$ \\
\hline $\mathrm{n}$ & 37 & 37 & 77 & 77 & 77 & 77 & 77 & 77 & 77 \\
\hline $\mathrm{SE}$ & 0.25 & 0.21 & 0.55 & 0.06 & 0.00 & 0.56 & 27.89 & 1.35 & 1.13 \\
\hline $\mathrm{CV}$ & 0.96 & 0.20 & 0.12 & 0.25 & 0.30 & 0.22 & 0.28 & 0.30 & 0.91 \\
\hline Median & 1.6 & -6.2 & 41.0 & 2.2 & 0.12 & 21.3 & 846.3 & 37.7 & 8.3 \\
\hline Minimum & -1.6 & -8.4 & 27.0 & 0.9 & 0.06 & 15.9 & 417.8 & 19.2 & 0.2 \\
\hline Maximum & 4.7 & -3.5 & 44.4 & 3.2 & 0.24 & 36.7 & 1576.4 & 77.2 & 47.2 \\
\hline \multicolumn{10}{|c|}{ ANOVA statistics for differences between species } \\
\hline Between-group MS (df) & $11.1(2)$ & $165.8(2)$ & $502.5(2)$ & $2.9(2)$ & $0.0(2)$ & $60.9(2)$ & $553539.6(2)$ & $1337.4(2)$ & $783.2(2)$ \\
\hline Within-group MS (df) & $2.1(143)$ & $2.6(143)$ & $10.5(278)$ & $0.15(278)$ & $0.0(278)$ & $16.2(278)$ & $107213.3(278)$ & $169.4(278)$ & $125.3(278)$ \\
\hline$F$ ratio & 5.2 & 65.0 & 48.1 & 19.0 & 0.2 & 3.7 & 5.2 & 7.9 & 6.3 \\
\hline $\mathrm{p}$ value & $<0.01$ & $<0.01$ & $<0.01$ & $<0.01$ & 0.855 & $<0.05$ & $<0.01$ & $<0.01$ & $<0.01$ \\
\hline
\end{tabular}



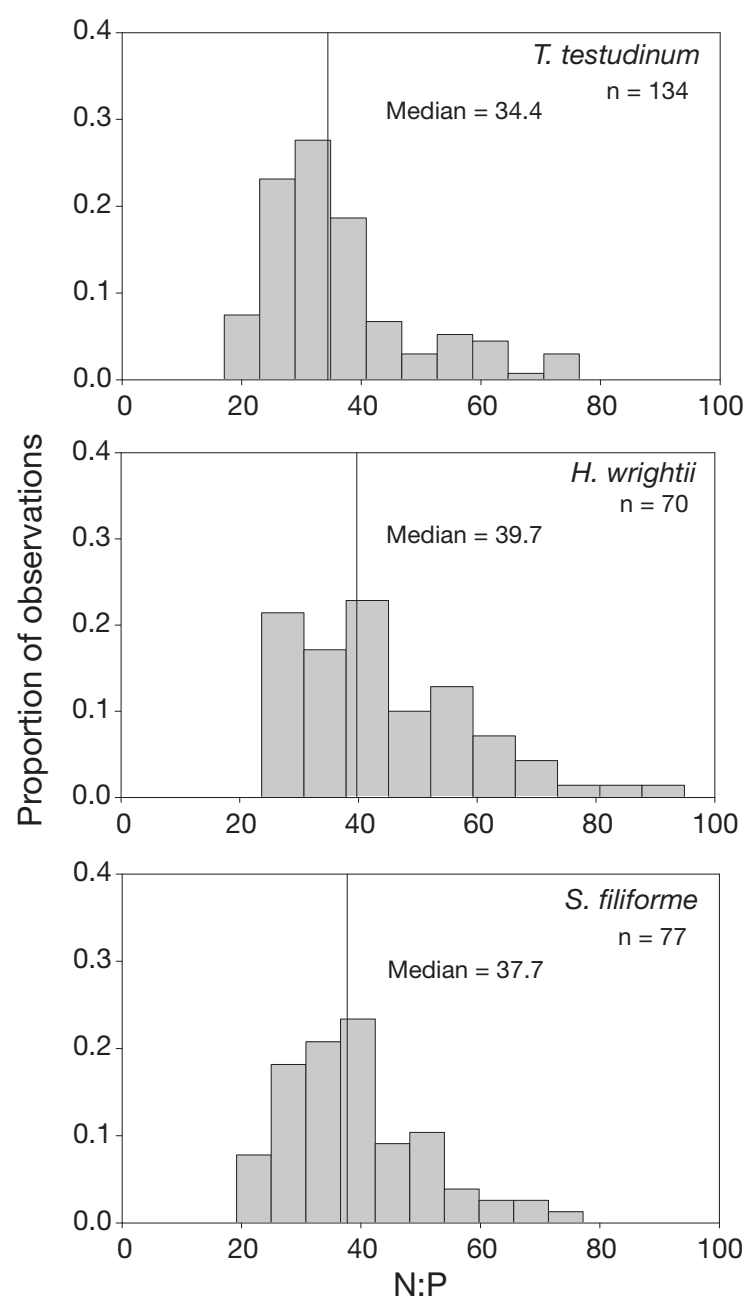

Fig. 2. Thalassia testudinum, Halodule wrightii, and Syringodium filiforme. Frequency distributions of elemental ratios analyzed during 1999 and 2000 across the FKNMS

wrightii $\delta^{13} \mathrm{C}$ values were significantly lower than both Thalassia testudinum and Syringodium filiforme (Table 1; Tukey's HSD, p < 0.001). S. filiforme displayed the highest $\delta^{13} \mathrm{C}$ values with a mean of $-6.2 \pm$ $0.2 \%$, a range of -3.5 to $-8.4 \%$, and a normal distribution. The $\delta^{13} \mathrm{C}$ values of $S$. filiforme were significantly higher than those of $T$. testudinum (Tukey's HSD, $\mathrm{p}<0.001) . T$. testudinum displayed intermediate $\delta^{13} \mathrm{C}$ values with a mean of $-8.6 \pm 0.2 \%$ and a range of -13.0 to $-5.3 \%$, whose values were normally distributed.

Stable nitrogen isotope values varied by $7.7,7.5$, and $6.3 \%$ for Thalassia testudinum, Halodule wrightii, and Syringodium filiforme, respectively (Table 1). T. testudinum displayed the highest $\delta^{15} \mathrm{~N}$ values of all species, with mean of $2.0 \pm 0.2 \%$ and a normal distribution (Fig. 5). T. testudinum displayed $\delta^{15} \mathrm{~N}$ values that were
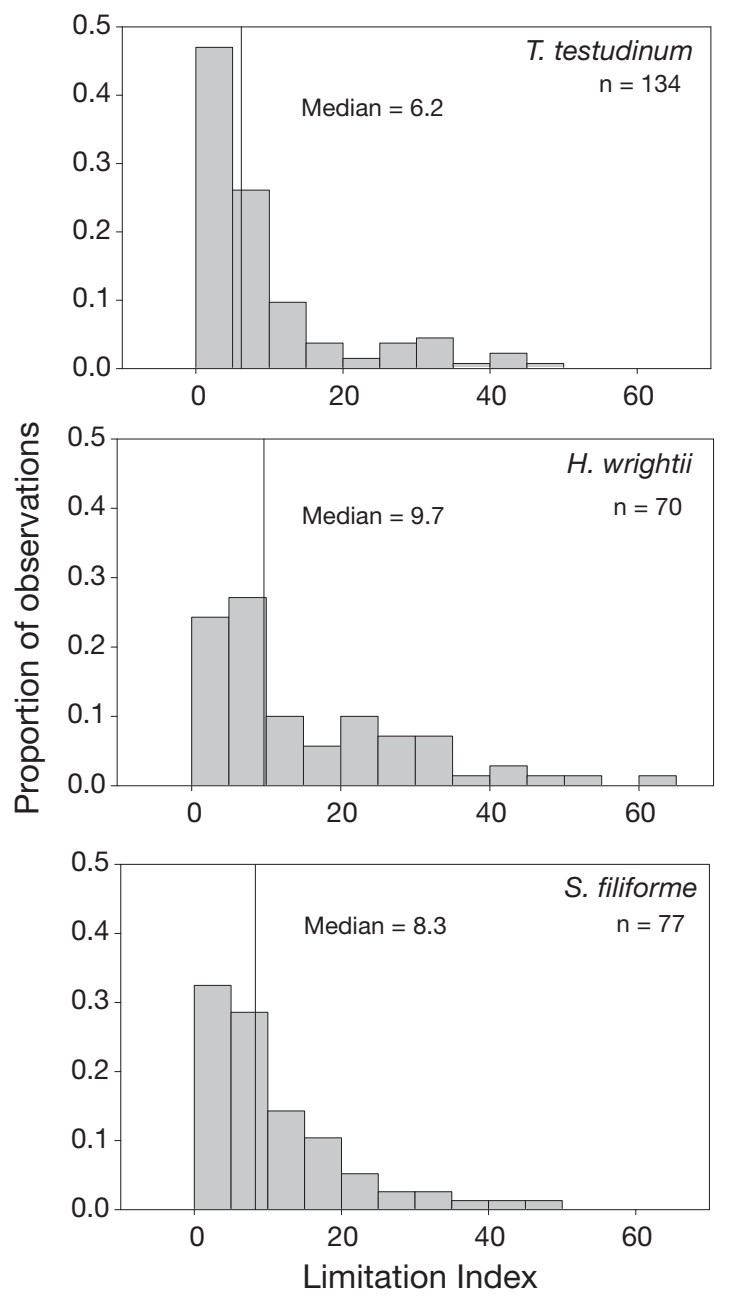

Fig. 3. Thalassia testudinum, Halodule wrightii, and Syringodium filiforme. Frequency distributions of Limitation Index values analyzed during 1999 and 2000 across the FKNMS

higher than those of $H$. wrightii (Table 1; Tukey's HSD, $\mathrm{p}<0.01$ ), yet similar to $S$. filiforme (Tukey's HSD, $\mathrm{p}=$ $0.45) . H$. wrightii displayed the lowest values, with a mean of $1.0 \pm 0.3 \%$ and a normal distribution. $H$. wrightii $\delta^{15} \mathrm{~N}$ values were similar to those of $S$. filiforme (Tukey's HSD, $\mathrm{p}=0.18$ ). $S$. filiforme displayed intermediate values, with a mean of $1.6 \pm 0.3 \%$ and a normal distribution.

Across the FKNMS, elemental and isotope ratios of all 3 seagrass species were correlated with site depth (Table 2, Fig. 6). The $\delta^{13} \mathrm{C}$ and N:P ratios were negatively correlated to site depth for all species and displayed similar variation with depth among species. The $\delta^{15} \mathrm{~N}$ ratio was positively correlated with site depth for Halodule wrightii and Syringodium filiforme, yet there was no correlation for Thalassia testudinum (Fig. 6). The variation in $\delta^{15} \mathrm{~N}$ with depth 

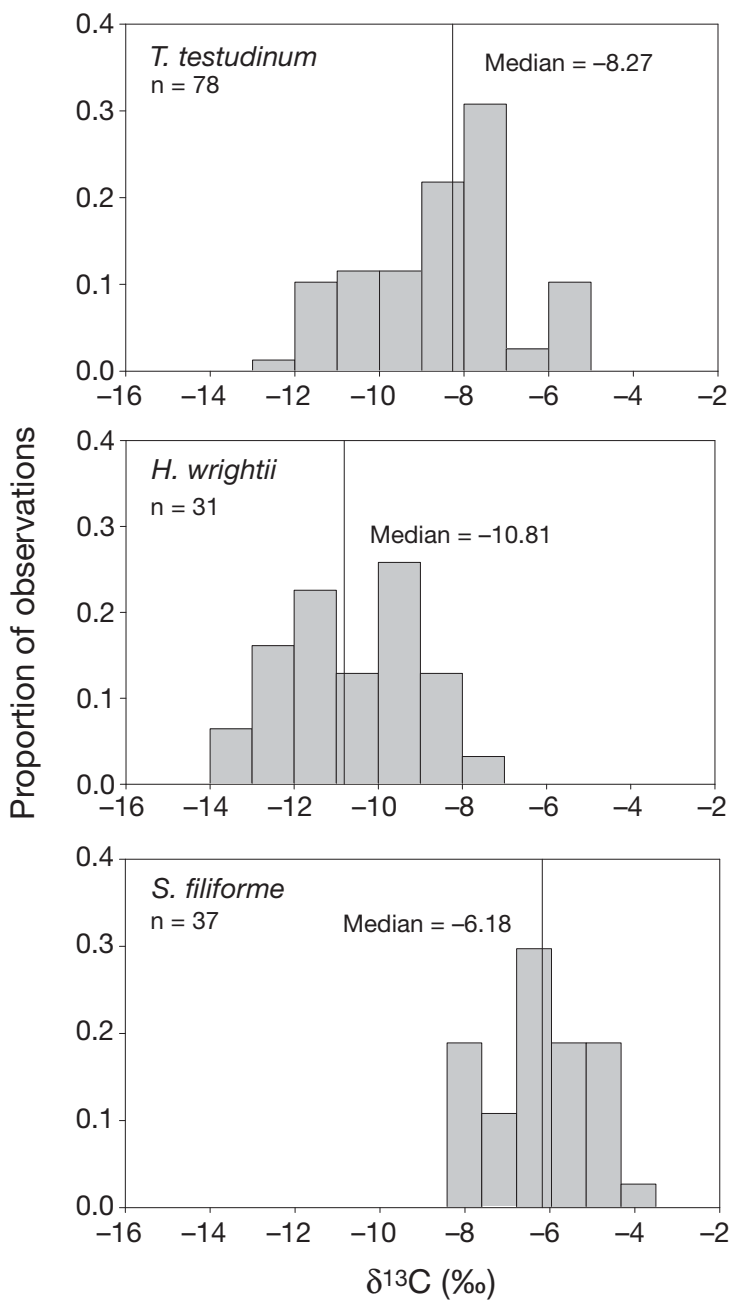

Fig. 4. Thalassia testudinum, Halodule wrightii, and Syringodium filiforme. Frequency distributions of stable carbon isotopes analyzed during 1999 across the FKNMS

was similar between $H$. wrightii and S. filiforme, and further analysis revealed that negative correlations between $\% \mathrm{~N}$ and $\delta^{15} \mathrm{~N}$ were restricted to the deeper offshore locations $(>4.3 \mathrm{~m})$. $S$. filiforme was the only species for which $\delta^{13} \mathrm{C}$ was correlated to $\delta^{15} \mathrm{~N}$. Correlations between elemental and isotope ratios were mixed depending upon species. In T. testudinum, N:P was positively correlated to $\delta^{13} \mathrm{C}$, yet uncorrelated to $\delta^{15} \mathrm{~N}$. $\quad S$. filiforme showed a negative correlation between N:P and $\delta^{15} \mathrm{~N}$, but no correlation between $\mathrm{N}: \mathrm{P}$ and $\delta^{13} \mathrm{C}$. In $H$. wrightii, N:P was both negatively correlated to $\delta^{15} \mathrm{~N}$ and positively correlated to $\delta^{13} \mathrm{C}$. LI values were negatively correlated to both site depth and $\delta^{15} \mathrm{~N}$ for $H$. wrightii and $S$. filiforme, but T. testudinum showed no correlation among these parameters. For all species LI was positively correlated to $\delta^{13} \mathrm{C}$.
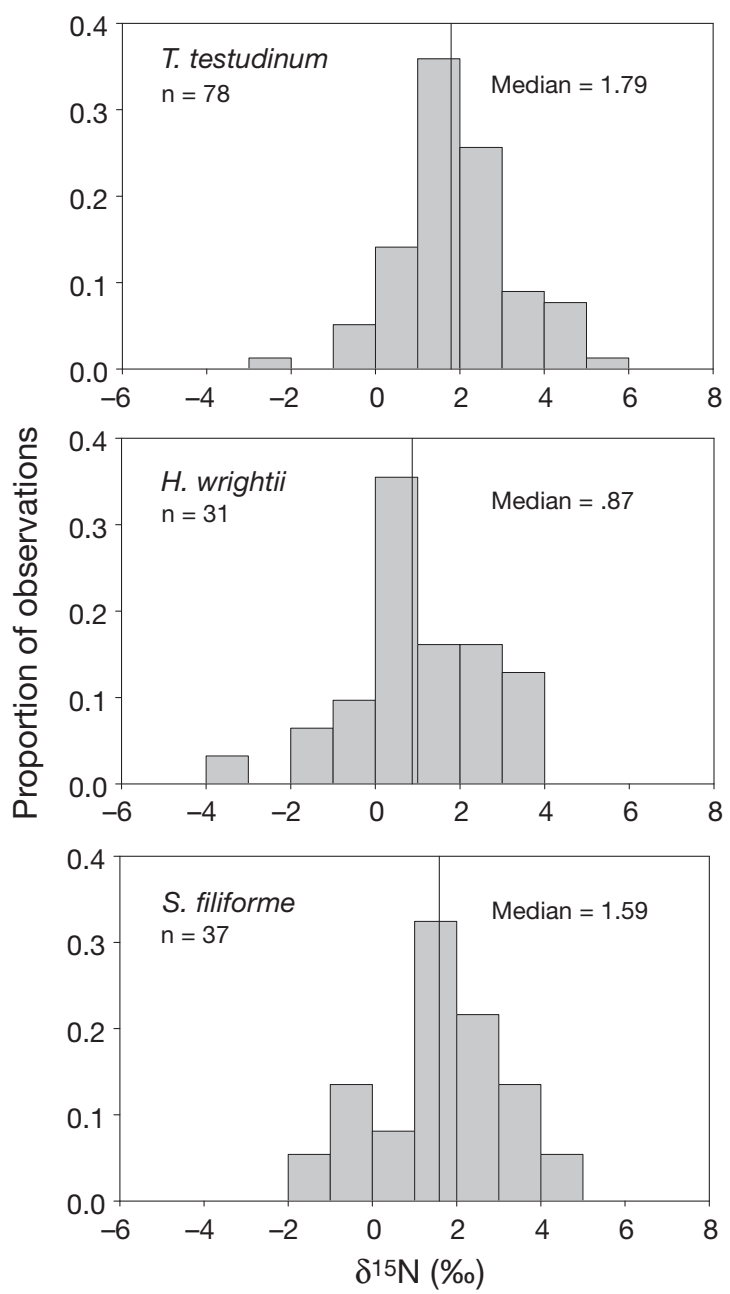

Fig. 5. Thalassia testudinum, Halodule wrightii, and Syringodium filiforme. Frequency distributions of stable nitrogen isotopes analyzed during 1999 across the FKNMS

\section{Interspecific variation at local scales across the FKNMS}

Of the sites that contained both Thalassia testudinum and Halodule wrightii (65 sites), N:P ratios and LI values were significantly higher for $H$. wrightii $(\mathrm{p}<0.001$; Fig. 7). When averaged for both years, T. testudinum had an N:P ratio and an LI of $35.9 \pm 1.4$ and $8.8 \pm 1.1$, respectively, at sites where it co-occurred with $H$. wrightii, while $H$. wrightii had an N:P ratio and an LI of $44.5 \pm 1.9$ and $15.8 \pm 1.8$ at the same sites. When growing in similar locations, significant differences were additionally detected in $\delta^{13} \mathrm{C}$ signatures, with $T$. testudinum (-8.9 \pm 0.4$)$ displaying isotopically heavier values than $H$. wrightii $(-10.4 \pm 0.3 ; \mathrm{p}<0.001 ;$ Fig. 8). There were no consistent significant differences in $\delta^{15} \mathrm{~N}$ between these 2 species at sites where they co-occurred. 
Table 2. Thalassia testudinum, Halodule wrightii, and Syringodium filiforme. Correlations (non-parametric Spearman's $\rho$ ) among elemental content, stable isotope ratios, and water depth for all 3 species. Correlation coefficients are designated above the diagonal, $p$-values for the pairwise comparisons are below the diagonal. Significant $(p<0.05)$ correlations are indicated in bold. LI: Limitation Index

\begin{tabular}{|c|c|c|c|c|c|c|c|}
\hline & Depth & $\delta^{15} \mathrm{~N}$ & $\delta^{13} \mathrm{C}$ & $\mathrm{C}: \mathrm{N}$ & $\mathrm{C}: \mathrm{P}$ & $\mathrm{N}: \mathrm{P}$ & LI \\
\hline \multicolumn{8}{|c|}{ Thalassia testudinum } \\
\hline Depth & & 0.113 & -0.655 & 0.377 & -0.131 & -0.322 & -0.208 \\
\hline$\delta^{15} \mathrm{~N}$ & 0.326 & & 0.162 & 0.272 & -0.073 & -0.182 & -0.012 \\
\hline$\delta^{13} \mathrm{C}$ & $<0.001$ & 0.158 & & -0.050 & 0.327 & 0.400 & 0.407 \\
\hline$C: N$ & 0.001 & 0.016 & 0.665 & & 0.281 & -0.159 & 0.057 \\
\hline $\mathrm{C}: \mathrm{P}$ & 0.255 & 0.526 & 0.003 & 0.013 & & 0.871 & 0.624 \\
\hline $\mathrm{N}: \mathrm{P}$ & 0.004 & 0.110 & $<0.001$ & 0.163 & $<0.001$ & & 0.700 \\
\hline LI & 0.067 & 0.919 & $<0.001$ & 0.621 & $<0.001$ & $<0.001$ & \\
\hline \multicolumn{8}{|c|}{ Halodule wrightii } \\
\hline Depth & & 0.415 & -0.609 & -0.090 & -0.391 & -0.466 & -0.547 \\
\hline$\delta^{15} \mathrm{~N}$ & 0.020 & & -0.210 & 0.494 & -0.052 & -0.407 & -0.423 \\
\hline$\delta^{13} \mathrm{C}$ & $<0.001$ & 0.258 & & 0.364 & 0.631 & 0.559 & 0.627 \\
\hline $\mathrm{C}: \mathrm{N}$ & 0.632 & 0.005 & 0.044 & & 0.613 & 0.173 & 0.163 \\
\hline $\mathrm{C}: \mathrm{P}$ & 0.029 & 0.781 & $<0.001$ & $<0.001$ & & 0.861 & 0.809 \\
\hline $\mathrm{N}: \mathrm{P}$ & 0.008 & 0.023 & 0.001 & 0.353 & $<0.001$ & & 0.958 \\
\hline LI & 0.001 & 0.018 & $<0.001$ & 0.381 & $<0.001$ & $<0.001$ & \\
\hline \multicolumn{8}{|c|}{ Syringodium filiforme } \\
\hline Depth & & 0.650 & -0.477 & 0.321 & -0.211 & -0.459 & -0.500 \\
\hline$\delta^{15} \mathrm{~N}$ & $<0.001$ & & -0.407 & 0.631 & 0.041 & -0.390 & -0.412 \\
\hline$\delta^{13} \mathrm{C}$ & 0.003 & 0.012 & & 0.019 & 0.253 & 0.279 & 0.360 \\
\hline$C: N$ & 0.052 & $<0.001$ & 0.909 & & 0.377 & -0.299 & -0.203 \\
\hline$C: P$ & 0.210 & 0.812 & 0.131 & 0.022 & & 0.733 & 0.668 \\
\hline $\mathrm{N}: \mathrm{P}$ & 0.004 & 0.017 & 0.095 & 0.072 & $<0.001$ & & 0.885 \\
\hline LI & 0.002 & 0.011 & 0.029 & 0.228 & $<0.001$ & $<0.001$ & \\
\hline
\end{tabular}

Halodule wrightii and Syringodium filiforme cooccurred at 38 sites and did not differ in either N:P ratios or LI (Fig. 7). For both sampling years, N:P ratios and LI were $43.9 \pm 2.6$ and $15.8 \pm 2.2$, respectively, for $H$. wrightii, and $42.3 \pm 2.2$ and $14.2 \pm 1.9$, respectively, for $S$. filiforme. Significant differences were detected in $\delta^{13} \mathrm{C}$ signatures, with $H$. wrightii displaying a value of $-10.1 \pm 0.3 \%$, as compared to the isotopically heavy $S$. filiforme $(-5.7 \pm 0.3 \%$; $\mathrm{p}<$ 0.001 ; Fig. 8). There were no consistent differences in $\delta^{15} \mathrm{~N}$ between $H$. wrightii and $S$. filiforme at sites where they co-occurred.

Thalassia testudinum and Syringodium filiforme cooccurred at 75 sites and displayed significant differences in both N:P ratios and LI at those sites $(\mathrm{p}<0.001$, $\mathrm{p}<0.01$ respectively). For both years, T. testudinum displayed an N:P ratio and LI of $34.2 \pm 1.1$ and $7.4 \pm 0.9$, respectively, while $S$. filiforme displayed an N:P ratio and LI of $38.8 \pm 1.4$ and $10.9 \pm 1.2$, respectively (Fig. 7). Additionally, $\delta^{13} \mathrm{C}$ signatures were statistically distinct, with $T$. testudinum $(-8.8 \pm 0.2 \%)$ displaying isotopically lighter values than $S$. filiforme $(-6.3 \pm 0.2 \%$; $\mathrm{p}<$ 0.001; Fig. 8). There were no significant differences in $\delta^{15} \mathrm{~N}$ between $T$. testudinum and $S$. filiforme at sites where they co-occurred.

\section{Temporal variation at local scales across the FKNMS}

There was marked seasonal variation in the $\delta^{13} \mathrm{C}$ values of Thalassia testudinum, Halodule wrightii, and Syringodium filiforme (Fig. 9). $\delta^{13} \mathrm{C}$ values for all 3 species were heaviest in the summer and fall months, and lightest in the winter months. The sine models described 51 to $73 \%$ of the variation in $\delta^{13} \mathrm{C}$ values (Table 3). Parameter estimates for $\alpha$ and $\Phi$ were not significantly different between species comparisons, indicating no interspecific differences in the degree of seasonal variation or the seasonal timing of $\delta^{13} \mathrm{C}$ values. Mean $\delta^{13} \mathrm{C}$ values of the sine models were significantly different for all species comparisons, indicating that the interspecific differences we documented above with our FKNMS-wide summer surveys were maintained throughout the year. Seasonal trends in $\delta^{15} \mathrm{~N}$ values were not detected for any species.

\section{DISCUSSION}

The elemental and isotope content of the seagrasses Thalassia testudinum, Halodule wrightii, and Syringo- 

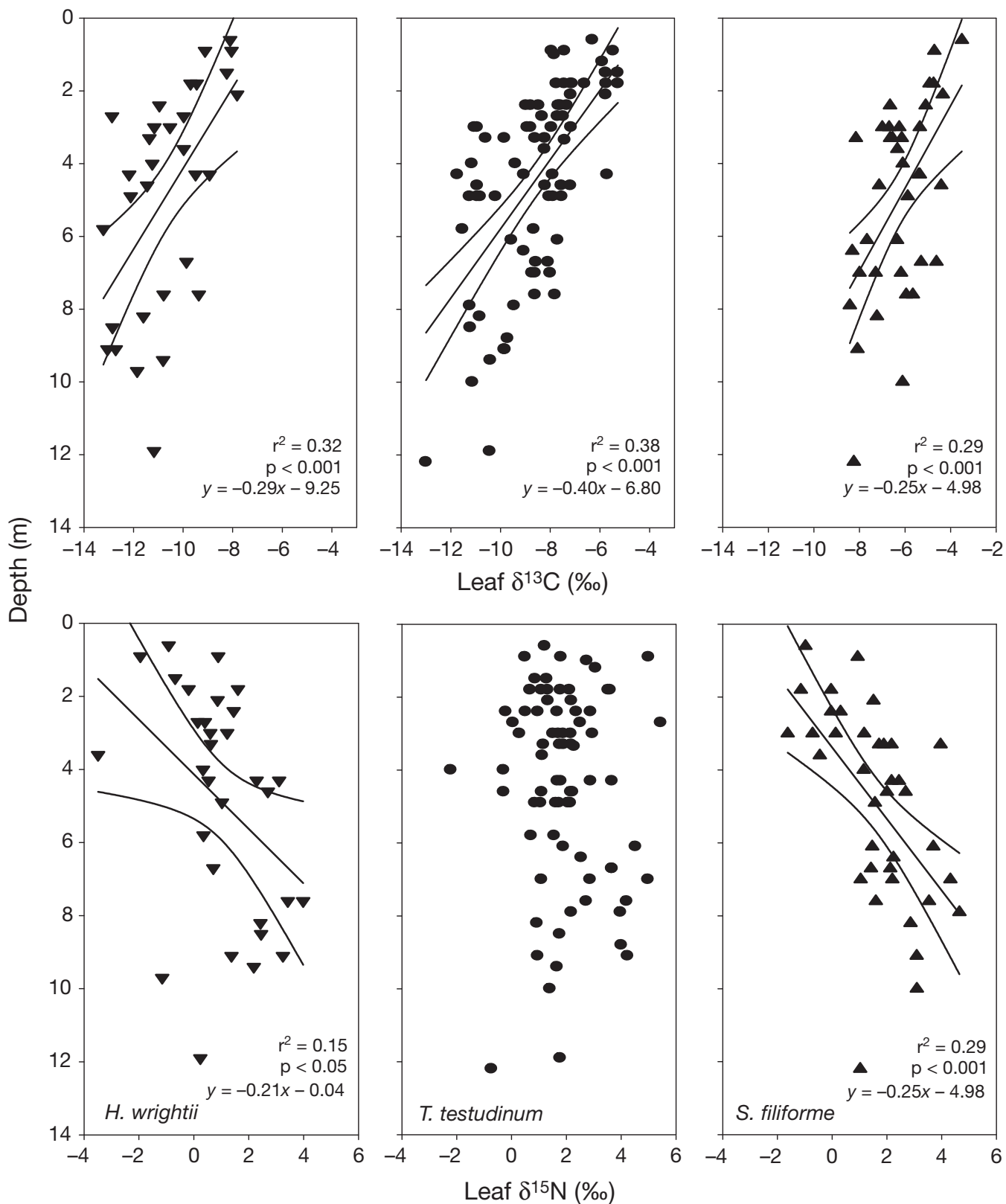

Fig. 6. Thalassia testudinum, Halodule wrightii, and Syringodium filiforme. Relationship between the $\delta^{13} \mathrm{C}$ and $\delta^{15} \mathrm{~N}$ isotope ratios and depth. Linear regression and $95 \%$ confidence interval of the regression are indicated

dium filiforme displayed marked interspecific variation at both local and broad spatial scales within the FKNMS. Both within- and between-species variations were nonrandom and demonstrated both the effects of environmental parameters and species-specific physiologies on the elemental and isotope content of seagrass tissues. This study highlights the importance of seagrass species identity in the evaluation of plant nutrient and isotope data for coastal monitoring efforts and food web analyses.

\section{Relationships between elemental ratios, isotope ratios, and water depth across the FKNMS}

Significant differences in $\delta^{13} \mathrm{C}$ were detected among all 3 seagrass species. The lightest $\delta^{13} \mathrm{C}$ values were displayed by Halodule wrightii, while Thalassia testudinum and Syringodium filiforme displayed the intermediate and heaviest values, respectively. Similarly, Lepoint et al. (2008) found that $S$. isoetifolium was more enriched in ${ }^{13} \mathrm{C}$ compared to Halodule sp. 

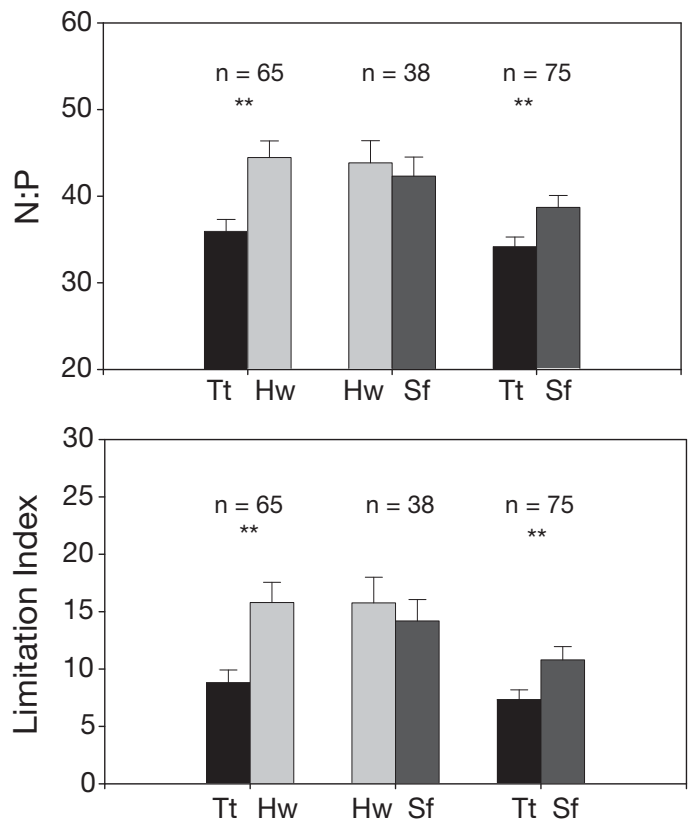

Fig. 7. Thalassia testudinum (Tt), Halodule wrightii (Hw), and Syringodium filiforme (Sf). Interspecific comparisons in N:P ratios and Limitation Index values where species co-occurred. Error bars are \pm 1 SE. Significant differences between species are indicated (paired $t$-tests, ${ }^{* *} \mathrm{p}<0.01$ ). The numbers of sites at which the species pairs co-occurred are given over each pair of bars
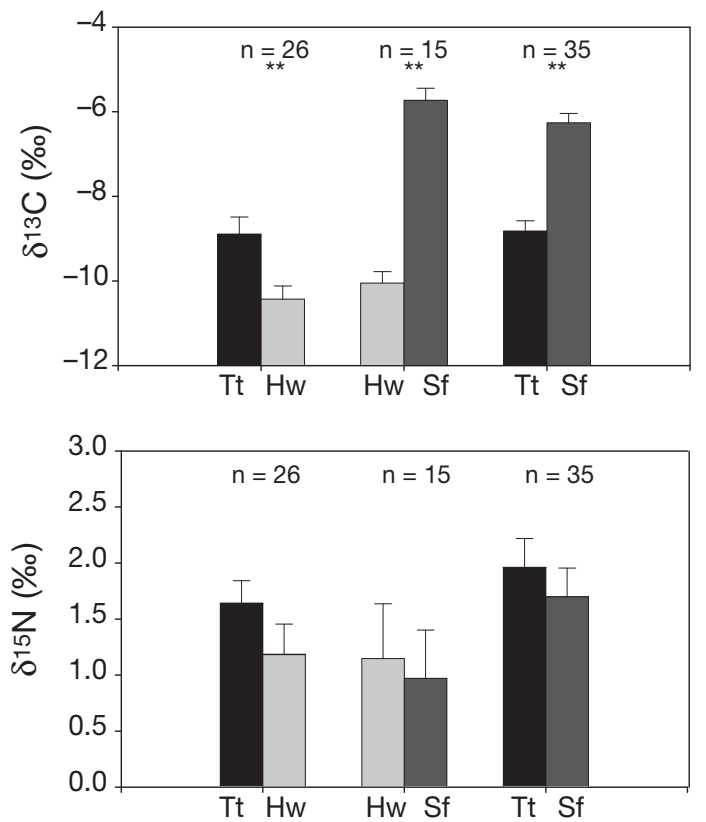

Fig. 8. Thalassia testudinum (Tt), Halodule wrightii (Hw), and Syringodium filiforme (Sf). Interspecific comparisons in $\delta^{13} \mathrm{C}$ and $\delta^{15} \mathrm{~N}$ isotope ratios where species co-occurred. Error bars are \pm 1 SE. Significant differences between species are indicated (paired $t$-tests, ${ }^{* *} p<0.01$ ). The numbers of sites at which the species pairs co-occurred are given over each pair of bars and T. hemprichii in Mozambique. In our study, the heaviest $\delta^{15} \mathrm{~N}$ was displayed by $T$. testudinum, which was significantly more positive than $H$. wrightii. The $\delta^{15} \mathrm{~N}$ value for $S$. filiforme was not statistically distinct from the other species. Large-scale trends in the stable isotope content of various seagrasses may provide
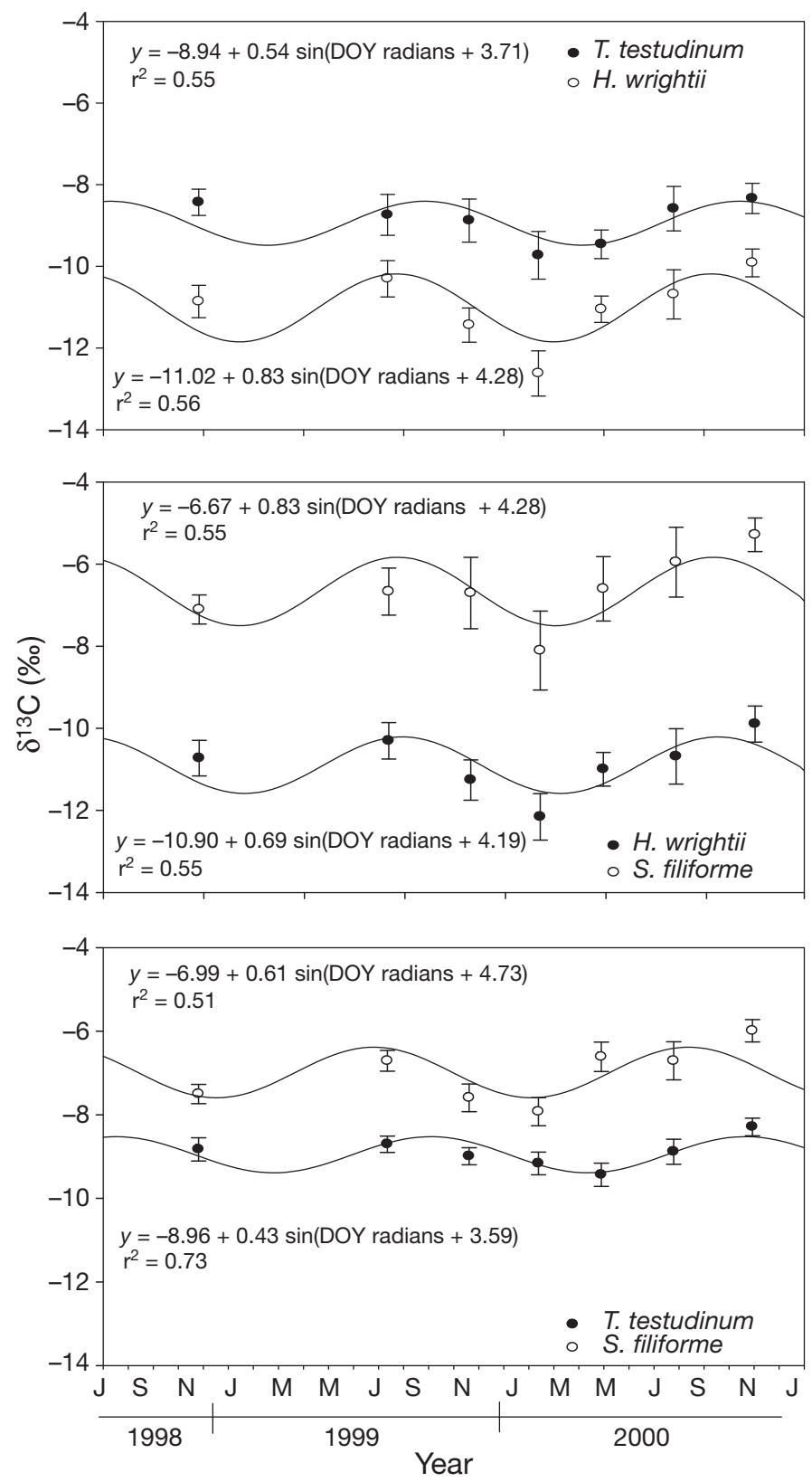

Fig. 9. Thalassia testudinum, Halodule wrightii, and Syringodium filiforme. Pairwise interspecific comparisons of seasonal patterns in $\delta^{13} \mathrm{C}$ of green leaves at the 30 permanent monitoring stations for co-occurring species. Each point represents the mean of the sites where both species of the pairwise comparisons co-occurred. Error bars represent $\pm 1 \mathrm{SE}$. The best fit sine model of the form $y=$ mean $+\alpha \times \sin ($ time $+\Phi)$ is shown, where $\alpha$ is the amplitude of a sine wave and $\Phi$ is a phase angle in radians $(2 \pi$ radians $=365 d)$. DOY: day of year 
Table 3. Thalassia testudinum, Halodule wrightii, and Syringodium filiforme. Parameter estimates for non-linear regressions of pairwise seagrass $\delta^{13} \mathrm{C}$ seasonal data from 1999 to 2000 at 30 permanent monitoring stations in FKNMS. DOY: day of year, $\alpha$ : amplitude of a sine wave, $\Phi$ : phase angle in radians $(2 \pi$ radians $=365 \mathrm{~d})$

\begin{tabular}{|c|c|c|c|c|c|}
\hline \multirow{2}{*}{$\begin{array}{l}\text { Species } \\
\text { comparison }\end{array}$} & \multirow[t]{2}{*}{ Equation } & \multicolumn{4}{|c|}{ Parameter estimates (95\% confidence interval) } \\
\hline & & $\mathrm{r}^{2}$ & Mean & $\alpha$ & $\Phi$ \\
\hline T. testudinum & $y=-8.94+0.54 \sin ($ DOY radians +3.71$)$ & 0.55 & $(-9.41,-8.48)$ & $(-0.140,1.22)$ & $(2.55,4.88)$ \\
\hline H. wrightii & $y=-11.02+0.83 \sin ($ DOY radians +4.28$)$ & 0.56 & $(-11.79,-10.24)$ & $(-0.208,1.87)$ & $(2.92,5.64)$ \\
\hline H. wrightii & $y=-10.90+0.69 \sin ($ DOY radians +4.19$)$ & 0.55 & $(-11.55,-10.25)$ & $(-0.193,1.57)$ & $(2.83,5.55)$ \\
\hline S. filiforme & $y=-6.67+0.83 \sin (\mathrm{DOY}$ radians +4.28$)$ & 0.55 & $(-7.45,-5.88)$ & $(-0.224,1.89)$ & $(2.9,5.66)$ \\
\hline T. testudinum & $y=-8.96+0.43 \sin ($ DOY radians +3.59$)$ & 0.73 & $(-9.2,-8.71)$ & $(0.068,0.797)$ & $(2.84,4.35)$ \\
\hline S. filiforme & $y=-6.99+0.61 \sin ($ DOY radians +4.73$)$ & 0.51 & $(-7.62,-6.36)$ & $(-0.216,1.43)$ & $(3.16,6.31)$ \\
\hline
\end{tabular}

information pertaining to physiological and ecological properties of each species. However, data at this large scale should be interpreted with caution, as trends may be confounded by spatial variations in the distribution of various seagrass species and in environmental conditions.

All 3 seagrass species showed significant correlations between $\delta^{13} \mathrm{C}$ values and site depth across the large spatial scale of the sanctuary (Fig. 6). Because light availability generally decreases with depth in the sea, this suggests that for each species, light plays an important role in regulating the $\delta^{13} \mathrm{C}$ content of seagrass tissues, as demonstrated in both laboratory and field studies (Durako \& Hall 1992, Abal et al. 1994, Grice et al. 1996). Likely this is because of reduced photosynthetic discrimination against the heavier isotope, leading to increased $\delta^{13} \mathrm{C}$ values at high light levels. Within a species, isotopically heavy values may indicate the possibility of photosynthetic carbon limitation during periods of high irradiance (Fourqurean et al. 2005). Field studies have shown that the inverse relationship between light and depth are reflected in the $\delta^{13} \mathrm{C}$ ratio of seagrass tissues elsewhere (Cooper \& DeNiro 1989, Lepoint et al. 2003, Fourqurean et al. 2007). In our study, $\delta^{13} \mathrm{C}$ values decreased by 0.40 , 0.29 , and $0.25 \% \mathrm{~m}^{-1}$ in depth for Thalassia testudinum, Halodule wrightii, and Syringodium filiforme, respectively. We do not think that the $\delta^{13} \mathrm{C}$-depth relationships are a function of variations in the isotopic signature of the DIC pool, as has been observed in regions where mineralization of organic matter from $\mathrm{C}_{3}$ mangroves causes isotopically depleted DIC that is incorporated into seagrass tissues (Fry \& Sherr 1984, Fleming et al. 1990, Lin et al. 1991). The FKNMS sites in close proximity to terrestrial DIC sources displayed the heaviest $\delta^{13} \mathrm{C}$ values, contrary to what would be expected if $\mathrm{C}_{3}$ material were affecting the isotope value of the DIC pool available to the seagrass community.

The $\delta^{15} \mathrm{~N}$ value of seagrass leaf material can be controlled by numerous factors. In addition to alterations in the isotopic composition of the source nitrogen pool, the relationship between plant nutrient demand and environmental availability represents a strong determinant of leaf isotope ratios. By reducing leaf growth rates and demand for nitrogen, reduced light as depth increases could influence leaf $\delta^{15} \mathrm{~N}$ as depressed demand increases discrimination against the heavier isotope. However, the net change in leaf $\delta^{15} \mathrm{~N}$ with increasing depth should be a consequence of the magnitude of the reduction in nitrogen demand relative to the changes in availability. For instance, in cases where nitrogen availability remains constant with increasing depth, we would expect a decrease in leaf $\delta^{15} \mathrm{~N}$ with increasing depth due to a depressed demand for nitrogen and higher discrimination against ${ }^{15} \mathrm{~N}$. Alternatively, cases in which leaf $\delta^{15} \mathrm{~N}$ shows little change with depth may represent scenarios whereby both nitrogen demand and availability concurrently decrease with depth, resulting in little alteration to ${ }^{15} \mathrm{~N}$ discrimination. Working with other species of seagrasses, Grice et al. (1996), Lepoint et al. (2003), and Fourqurean et al. (2007) all found no significant change in leaf $\delta^{15} \mathrm{~N}$ across large depth and light gradients, although they did not investigate the causal mechanisms for those observations. Lastly, if nitrogen availability decreases dramatically with increasing depth, we could, despite reductions in nitrogen demand, find higher leaf $\delta^{15} \mathrm{~N}$ values as depth increases. We believe this to be the case in our study, as the observed relationships between $\delta^{15} \mathrm{~N}$ and depth are a consequence of the distribution of deep-water sites within a landscape of variable nitrogen availability. The leaf $\delta^{15} \mathrm{~N}$ value of both Halodule wrightii and Syringodium filiforme was positively correlated to site depth and negatively correlated to both N:P ratios and LI. Such correlations suggest that as nitrogen becomes less available and nutrient limitation increases, these seagrasses reduce fractionation of the available DIN pool. Additionally, the negative correlation between $\% \mathrm{~N}$ and $\delta^{15} \mathrm{~N}$ was only significant for the deeper sites under similar light regimes, further indicating that 
environmental availability was driving the relationship between depth and $\delta^{15} \mathrm{~N}$. This indicates that the reduced DIN discrimination in $H$. wrightii and $S$. filiforme increasingly occurs at deeper offshore locations, where primary production is nitrogen-limited (Fourqurean \& Zieman 2002, Ferdie \& Fourqurean 2004, Fourqurean et al. 2005). However, this trend did not hold for Thalassia testudinum, which exhibited no correlation between $\delta^{15} \mathrm{~N}$ values and site depth or N:P ratios. Thus, these correlations were only evident for the fastest-growing seagrasses $(H$. wrightii and $S$. filiforme), which may use nutrient resources more rapidly than T. testudinum, leading to decreases in DIN fractionation and higher LI compared to the slower-growing T. testudinum. Further experimentation is needed to detail these processes.

The fact that interspecific differences in stable carbon isotopes remain statistically distinct across large spatial scales may imply that seagrass physiology plays a dominant role in determining interspecific variation in $\delta^{13} \mathrm{C}$. Average values for Halodule wrightii were $2.0 \%$ lighter than Thalassia testudinum and $4.5 \%$ lighter than Syringodium filiforme. Such differences might be attributed to the varied mechanisms of bicarbonate acquisition and internal carbon recycling within marine macrophytes (Fry \& Sherr 1984, Fry et al. 1985, Hemminga \& Mateo 1996, Fourqurean et al. 2007), or caused by morphological variations in leaves (Lepoint et al. 2008). To various degrees, seagrass photosynthetic carbon demand may be met via a combination of diffusive $\mathrm{CO}_{2}$ transport and active $\mathrm{HCO}_{3}{ }^{-}$ import (Invers et al. 1999, 2001). While dissolved $\mathrm{CO}_{2}$ has an isotopic carbon signature of ca. $-9 \%, \mathrm{HCO}_{3}{ }^{-}$in marine waters has an isotopic signature of $0 \%$. Preferential fixation of bicarbonate from the inorganic carbon pool should result in seagrass tissue that is enriched in ${ }^{13} \mathrm{C}$ (Hemminga \& Mateo 1996). Interspecific variation in seagrass $\delta^{13} \mathrm{C}$ values may reflect previously documented interspecific variation in bicarbonate acquisition mechanisms, as some species display enhanced $\mathrm{HCO}_{3}{ }^{-}$utilization efficiencies (Bjork et al. 1997, Invers et al. 1999, Schwarz et al. 2000, Uku et al. 2005). Our field data suggest that $S$. filiforme may rely more on $\mathrm{HCO}_{3}^{-}$as a carbon source than $H$. wrightii or T. testudinum, a hypothesis that should be explored.

Internal recycling of $\mathrm{CO}_{2}$ has been proposed as an alternate mechanism that can influence the stable carbon isotope value of benthic macrophytes (Cooper 1989, Abal et al. 1994, Grice et al. 1996). Seagrass species that have enhanced lacunal volume may display increased recycling of internal carbon pools and reduced isotopic discrimination. As internal recycling of $\mathrm{CO}_{2}$ reduces the degree of carbon back-diffusion, RUBISCO operates in an increasingly closed environ- ment, converting all inorganic carbon into organic products, resulting in isotopically heavier $\delta^{13} \mathrm{C}$ signatures (Sharkey \& Berry 1985). Internal recycling may therefore serve to complicate the relationship between the $\delta^{13} \mathrm{C}$ of source DIC and the $\delta^{13} \mathrm{C}$ of seagrass tissues. Our data are consistent with more efficient internal recycling of $\mathrm{CO}_{2}$ in Syringodium filiforme than in Halodule wrightii or Thalassia testudinum. It is evident that the factors contributing to the characteristic $\delta^{13} \mathrm{C}$ value of seagrass species are complex and require studies focused on detailing the contributions that carbon acquisition mechanisms, seagrass lacunal volume, and rates of $\mathrm{CO}_{2}$ recycling make to the overall isotopic signature.

Interspecific variation in $\delta^{15} \mathrm{~N}$ across FKNMS revealed significant differences between Thalassia testudinum and Halodule wrightii; however, it remains unclear whether this trend is due to differences in the degree of isotope fractionation among species, or due to spatial trends in the isotope composition of source DIN and seagrass abundance. Across a large spatial scale, T. testudinum was isotopically heavier than $H$. wrightii, indicating decreased fractionation among nitrogen isotopes. Successional studies have demonstrated T. testudinum as a climax species with the ability to thrive in nutrient-poor environments, and $H$. wrightii as an early successional species thriving under more eutrophic conditions (Fourqurean et al. 1995). Across large spatial scales, T. testudinum may monospecifically occupy the most oligotrophic locations with the lowest DIN pools, resulting in decreased fractionation of the nitrogen isotope, accounting for heavier $\delta^{15} \mathrm{~N}$ values; $H$. wrightii, occupying areas with higher DIN pools, may have higher rates of fractionation, lowering $\delta^{15} \mathrm{~N}$ values. Such results are not contradictory to previous findings concerning the correlation between $\delta^{15} \mathrm{~N}$ and depth. Despite $H$. wrightii displaying decreased $\delta^{15} \mathrm{~N}$ fractionation with depth, overall this species remains isotopically lighter than $T$. testudinum because it is excluded from the highly oligotrophic deeper waters solely occupied by $T$. testudinum.

Elemental comparisons across FKNMS revealed that Thalassia testudinum had significantly lower N:P ratios and LI than Halodule wrightii $(\mathrm{p}<0.01)$, while Syringodium filiforme was not distinct from either $T$. testudinum or $H$. wrightii. Overall, intraspecific variation at this scale is attributable to the balance between the availability nutrient resources ( $\mathrm{N}$ and $\mathrm{P}$ ) and rates of seagrass productivity (Fourqurean et al. 2005). However, interspecific differences in the N:P ratios of T. testudinum and $H$. wrightii may result from life history differences between these 2 species. The early successional status and higher growth rates of $H$. wrightii may account for increased deviation from seagrass Redfield N:P stoichiometry. Nutrient demand is higher 
for $H$. wrightii than for $T$. testudinum (Fourqurean et al. 1992b); thus, despite possibly being limited to sites elevated in nutrient concentrations, the fast growth rates of $H$. wrightii still produce $\mathrm{N}$ :P ratios that are drastically altered from seagrass Redfield values. Ecologically, T. testudinum is a late successional species, and the life history strategy of reduced growth rates may allow $T$. testudinum to produce biomass with N:P ratios closer to the ideal Redfield value of 30:1. The extensive investment in underground biomass (root/ rhizome complex) may additionally allow $T$. testudinum to exploit sediment nutrient pools unavailable to other species, thus bringing stoichiometric ratios closer to 30:1. However, across landscape scales, elemental variation due to life history differences are difficult to separate from elemental variation due to spatial trends in nutrients, light, and seagrass abundance. For example, if $T$. testudinum were relatively more abundant in deeper, lower light environments, then lower productivities and reduced N:P ratios may be attributable to this spatial environmental factor, and not to species-specific physiological/ecological properties.

\section{Interspecific variation at local scales within the FKNMS}

Within-site, local comparisons between species control for spatial gradients in abiotic factors (light and nutrients); hence differences in elemental and isotope compositions do not reflect environmental variation and may be attributed to differences in species-specific physiological and ecological properties. Congruence or discordance of local trends with broad spatial trends reveals whether interspecific variation is due to physiological attributes or wide-ranging abiotic variation. We find that at the local scale, interspecific trends in stable carbon isotopic content and elemental ratios are generally maintained, while trends in stable nitrogen isotopic content are not consistent with the trends observed at broad spatial scales.

Local-scale interspecific trends in $\delta^{13} \mathrm{C}$ agree with broad-scale trends, revealing that species-specific physiological attributes are dominant factors in controlling taxon-specific $\delta^{13} \mathrm{C}$ values. At the same location, Halodule wrightii was significantly lighter than both Thalassia testudinum and Syringodium filiforme, and $T$. testudinum was significantly lighter than $S$. filiforme, but heavier than $H$. wrightii (Fig. 8), suggesting that the interspecific trends at the broad scale of the FKNMS are functions of the physiological attributes of carbon acquisition. Using this model, H. wrightii may represent a seagrass species that, while displaying $\mathrm{HCO}_{3}{ }^{-}$use, exhibits high rates of carbon back diffusion (low $\mathrm{CO}_{2}$ recycling), and thus fails to fix a large portion of incorporated carbon, allowing for increased isotopic discrimination. Conversely, S. filiforme may represent a species that displays reduced carbon back diffusion (high $\mathrm{CO}_{2}$ recycling), and thus fixes a large majority of imported carbon. The apparent dependence of seagrass $\delta^{13} \mathrm{C}$ on specific carbon acquisition properties has terrestrial analogues, as seen in the $\delta^{13} \mathrm{C}$ variation between $\mathrm{C}_{3}$ and $\mathrm{C}_{4}$ plants. In addition to using phosphoenolpyruvate carboxylase to fix $\mathrm{CO}_{2}$, which discriminates less against ${ }^{13} \mathrm{C}$ than RUBISCO, $\mathrm{C}_{4}$ plants limit carbon diffusion out of the leaves with morphological adaptations (e.g. bundle sheaths), and variations in the rates of $\mathrm{CO}_{2}$ back diffusion have been noted to affect the $\delta^{13} \mathrm{C}$ values of $\mathrm{C}_{4}$ vegetation (Farquhar et al. 1989). While seagrasses are all $\mathrm{C}_{3}$ plants (Beer \& Wetzel 1982), the degree of bicarbonate use, extent of internal recycling, and specific leaf morphology (Lepoint et al. 2008) are likely to play analogous roles in explaining interspecific variation in the $\delta^{13} \mathrm{C}$ values of marine plants.

Local scale interspecific trends in stable nitrogen isotope values displayed non-significant differences among all seagrass species. The significant differences observed between Thalassia testudinum and Halodule wrightii at the broad scale were not observed within sites, indicating that $\delta^{15} \mathrm{~N}$ trends across FKNMS were predominantly a result of spatial variation in seagrass distribution and DIN pools, as opposed to interspecific physiological differences in nitrogen uptake and fractionation. However, we note that the reduced sampling effort of the within-site comparisons may have limited our ability to detect a significant difference in $\delta^{15} \mathrm{~N}$ between $T$. testudinum and $H$. wrightii, warranting future studies.

Interspecific variation in elemental ratios revealed that, similar to broad-scale patterns, Thalassia testudinum displayed significantly lower N:P ratios than Halodule wrightii when growing at the same location. At the local scale, we also found that $T$. testudinum had significantly lower N:P ratios than $S$. filiforme, previously undocumented at broader scales. There was no difference in N:P ratios between $H$. wrightii and $S$. filiforme. By removing spatial variation in environmental variables and seagrass distribution, interspecific differences in elemental composition reflect important differences in the ecology of these seagrass species. When co-occurring with T. testudinum, and exposed to similar nutrient and light conditions, rapidly growing early successional species ( $H$. wrightii and $S$. filiforme) are further removed from seagrass Redfield stoichiometry, indicating heavily nutrient-limited growth (particularly with respect to P). The slower growth rates of T. testudinum may allow for reduced nutrient-limited growth and an enhanced ability to thrive under olig- 
otrophic conditions. The altered elemental ratios of cooccurring seagrasses further suggest that nutrient limitation must be viewed with respect to a specific primary producer, and may not be applicable to other species within the same location.

\section{Temporal variation in seagrass isotope content}

As previously documented for Thalassia testudinum (Fourqurean et al. 2005) the $\delta^{13} \mathrm{C}$ of Halodule wrightii and Syringodium filiforme fluctuate seasonally. Interspecific variation in seagrass $\delta^{13} \mathrm{C}$ values was not limited to the summer conditions of high productivity, as we would expect if differential $\mathrm{CO}_{2}$ acquisition were leading to different amounts of isotopic discrimination during summer periods of maximum photosynthesis. Interspecific differences in $\delta^{13} \mathrm{C}$ were maintained throughout the year, with peaks during the highly productive summer periods and lows during the less productive winter periods. The constant interspecific variation suggests that species-specific $\delta^{13} \mathrm{C}$ values are a result of physiologically based traits and are unlikely the result of altered or adaptive carbon acquisition mechanisms during the summer months. Thus, despite seasonal variation, seagrass $\delta^{13} \mathrm{C}$ values remain significantly distinct throughout the year and maintain the similar trends ( $S$. filiforme $>T$. testudinum $>H$. wrighii) found during the summer surveys.

Seasonal variation in seagrass $\delta^{13} \mathrm{C}$ values have been correlated to seasonal patterns in productivity, governed both by light availability and temperature (Fourqurean et al. 2001, 2005, 2007). Drawdown of $\mathrm{CO}_{2}$ pools during the summer months, combined with limited $\mathrm{CO}_{2}$ diffusion rates, may decrease the degree of fractionation displayed by RUBISCO. Similar seasonal trends have been noted for a number of phytoplankton studies, and may indicate carbon limitation during periods of high productivity (Fogel et al. 1992). Alternately, it is possible that increased summer productivities may enhance bicarbonate use within all seagrass species, elevating $\delta^{13} \mathrm{C}$ values and mitigating C-limited photosynthesis. The amplitudes of the sine models were not statistically distinct among species, and thus there was no difference in the degree of seasonal variation. These findings contrasted with our original hypotheses, which expected the fastestgrowing seagrass species ( $H$. wrightii and $S$. filiforme) to exhibit the greatest amplitude in seasonal variation, suggesting that while taxonomic differences strongly influence the mean $\delta^{13} \mathrm{C}$ value, seasonal environmental factors strongly control annual variation within each species. There were no interspecific differences in $\Phi$, and therefore the timing of the seasonal response (summer peaks and winter lows), among species. It is evident that while seasonal responses are not different in all 3 seagrass species, their mean $\delta^{13} \mathrm{C}$ value remains markedly distinct throughout the annual cycle.

Seasonal variation in seagrass $\delta^{15} \mathrm{~N}$ was undetected for all species. Seasonal cycles in stable nitrogen isotope content have been previously documented for Thalassia testudinum in South Florida (Fourqurean et al. 2005); thus the lack of a seasonal pattern in our study may be due to an insufficient sampling size for this particular isotope parameter.

The elemental and stable isotope content of seagrass species in South Florida displays considerable interspecific variation at both broad and local spatial scales. Here we present the first documentation of speciesspecific variation in South Florida, by which carbon isotope values may be associated with physiological differences in carbon acquisition, and elemental ratios may be associated with ecological differences in seagrass growth rates. As such, the use of these parameters as indicators of ecosystem properties must carefully consider the species of marine plant being studied. In addition to previously documented spatial and temporal variation, taxonomic differences in isotope and elemental content can introduce additional variation of significant magnitude. Interspecific differences are non-random, and thus understanding how seagrass species differ in isotope and elemental content will aid in the interpretation of studies that examine the food web and nutrient dynamics of multispecies seagrass ecosystems.

Acknowledgements. This work was supported by the Florida Keys Water Quality Protection Program Seagrass Monitoring Project funded by grants from NOAA's South Florida Program (contract no. NA06NOS4780105) and the USEPA (Assistance Agreement X797468102). This manuscript benefited from discussions with post-doctoral fellows, students, and technicians in the laboratory of J.W.F. Among the many people who collected and processed data as part of the larger project, we are especially indebted to L. Rutten, S. Escorcia, and P. Parker. W.T. Anderson at the FIU Stable Isotope Laboratory analyzed our stable isotope samples. This is contribution number 438 from the Southeast Environmental Research Center at FIU.

\section{LITERATURE CITED}

Abal EG, Loneragan N, Bowen P, Perry CJ, Udy JW, Dennison WC (1994) Physiological and morphological responses of the seagrass Zostera capricorni Aschers to light-intensity. J Exp Mar Biol Ecol 178:113-129

Agren GI (2004) The C:N:P stoichiometry of autotrophs theory and observations. Ecol Lett 7:185-191

Armitage AR, Frankovich TA, Heck KL, Fourqurean JW (2005) Experimental nutrient enrichment causes complex changes in seagrass, microalgae, and macroalgae community structure in Florida Bay. Estuaries 28:422-434

Atkinson MJ, Smith SV (1983) C-N-P ratios of benthic marine plants. Limnol Oceanogr 28:568-574 
Beer S, Wetzel RG (1982) Photosynthetic carbon fixation pathways in Zostera marina and 3 Florida seagrasses. Aquat Bot 13:141-146

Bjork M, Weil A, Semesi S, Beer S (1997) Photosynthetic utilisation of inorganic carbon by seagrasses from Zanzibar, East Africa. Mar Biol 129:363-366

> Cooper LW (1989) Patterns of carbon isotopic variability in eelgrass, Zostera marina L, from Izembek Lagoon, Alaska. Aquat Bot 34:329-339

Cooper LW, DeNiro MJ (1989) Stable carbon isotope variability in the seagrass Posidonia oceanica: evidence for light intensity effects. Mar Ecol Prog Ser 50:225-229

Dawson TE, Mambelli S, Plamboeck AH, Templer PH, Tu KP (2002) Stable isotopes in plant ecology. Annu Rev Ecol Syst 33:507-559

> Duarte CM (1990) Seagrass nutrient content. Mar Ecol Prog Ser 67:201-207

Duarte CM (1992) Nutrient concentration of aquatic plants Patterns across species. Limnol Oceanogr 37:882-889

> Durako MJ, Hall MO (1992) Effects of light on the stable carbon isotope composition of the seagrass Thalassia testudinum. Mar Ecol Prog Ser 86:99-101

> Durako MJ, Sackett WM (1993) Effects of $\mathrm{CO}_{2(\mathrm{Aq})}$ on the carbon isotopic composition of the seagrass Thalassia testudinum Banks ex König (Hydrocharitaceae). J Exp Mar Biol Ecol 169:167-180

Farquhar GD, Ehleringer JR, Hubick KT (1989) Carbon isotope discrimination and photosynthesis. Annu Rev Plant Physiol Plant Mol Biol 40:503-537

Ferdie M, Fourqurean JW (2004) Responses of seagrass communities to fertilization along a gradient of relative availability of nitrogen and phosphorus in a carbonate environment. Limnol Oceanogr 49:2082-2094

Fleming M, Lin GH, Sternberg LDL (1990) Influence of mangrove detritus in an estuarine ecosystem. Bull Mar Sci 47 : 663-669

Fogel ML, Cifuentes LA, Velinsky DJ, Sharp JH (1992) Relationship of carbon availability in estuarine phytoplankton to isotopic composition. Mar Ecol Prog Ser 82:291-300

Fourqurean JW, Zieman JC (2002) Nutrient content of the seagrass Thalassia testudinum reveals regional patterns of relative availability of nitrogen and phosphorus in the Florida Keys USA. Biogeochemistry 61:229-245

Fourqurean JW, Zieman JC, Powell GVN (1992a) Phosphorus limitation of primary production in Florida Bay - Evidence from C-N-P ratios of the dominant seagrass Thalassia testudinum. Limnol Oceanogr 37:162-171

Fourqurean JW, Zieman JC, Powell GVN (1992b) Relationships between porewater nutrients and seagrasses in a subtropical carbonate environment. Mar Biol 114:57-65

Fourqurean JW, Powell GVN, Kenworthy WJ, Zieman JC (1995) The effects of long-term manipulation of nutrient supply on competition between the seagrasses Thalassia testudinum and Halodule wrightii in Florida Bay. Oikos 72:349-358

Fourqurean JW, Moore TO, Fry B, Hollibaugh JT (1997) Spatial and temporal variation in C:N:P ratios, $\delta^{15} \mathrm{~N}$ and $\delta^{13} \mathrm{C}$ of eelgrass Zostera marina as indicators of ecosystem processes, Tomales Bay, California, USA. Mar Ecol Prog Ser 157:147-157

Fourqurean JW, Willsie A, Rose CD, Rutten LM (2001) Spatial and temporal pattern in seagrass community compo-

Editorial responsibility: Just Cebrian,

Dauphin Island, Alabama, USA sition and productivity in south Florida. Mar Biol 138: 341-354

Fourqurean JW, Escorcia SP, Anderson WT, Zieman JC (2005) Spatial and seasonal variability in elemental content, $\delta^{13} \mathrm{C}$, and $\delta^{15} \mathrm{~N}$ of Thalassia testudinum from South Florida and its implications for ecosystem studies. Estuaries 28: $447-461$

Fourqurean JW, Marba N, Duarte CM, Diaz-Almela E, RuizHalpern S (2007) Spatial and temporal variation in the elemental and stable isotopic content of the seagrasses Posidonia oceanica and Cymodocea nodosa from the Illes Balears, Spain. Mar Biol 151:219-232

Fry B, Sherr EB (1984) $\delta^{13} \mathrm{C}$ Measurements as indicators of carbon flow in marine and fresh-water ecosystems. Contrib Mar Sci 27:13-47

Fry B, Macko SA, Zieman JC (1985) Review of stable isotopic investigations of food webs in seagrass meadows. Fla Mar Res Publ 42:189-209

Grice AM, Loneragan NR, Dennison WC (1996) Light intensity and the interactions between physiology, morphology and stable isotope ratios in five species of seagrass. J Exp Mar Biol Ecol 195:91-110

- Hemminga MA, Mateo MA (1996) Stable carbon isotopes in seagrasses: variability in ratios and use in ecological studies. Mar Ecol Prog Ser 140:285-298

Invers O, Perez M, Romero J (1999) Bicarbonate utilization in seagrass photosynthesis: role of carbonic anhydrase in Posidonia oceanica (L) Delile and Cymodocea nodosa (Ucria) Ascherson. J Exp Mar Biol Ecol 235:125-133

Invers O, Zimmerman RC, Alberte RS, Perez M, Romero J (2001) Inorganic carbon sources for seagrass photosynthesis: an experimental evaluation of bicarbonate use in species inhabiting temperate waters. J Exp Mar Biol Ecol 265: 203-217

Lepoint G, Dauby P, Fontaine M, Bouquegneau JM, Gobert S (2003) Carbon and nitrogen isotopic ratios of the seagrass Posidonia oceanica: depth-related variations. Bot Mar 46: $555-561$

> Lepoint G, Frederich B, Gobert S, Parmentier E (2008) Isotopic ratios and elemental contents as indicators of seagrass C processing and sewage influence in a tropical macrotidal ecosystem (Madagascar, Mozambique Channel). Sci Mar 72:109-117

Lin GH, Banks T, Sternberg L (1991) Variation in $\delta^{13} \mathrm{C}$ values for the seagrass Thalassia testudinum and its relations to mangrove carbon. Aquat Bot 40:333-341

> McMillan C, Parker PL, Fry B $(1980){ }^{13} \mathrm{C} /{ }^{12} \mathrm{C}$ ratios in seagrasses. Aquat Bot 9:237-249

Peterson BJ, Fry B (1987) Stable isotopes in ecosystem studies. Annu Rev Ecol Syst 18:293-320

Schwarz AM, Bjork M, Buluda T, Mtolera H, Beer S (2000) Photosynthetic utilisation of carbon and light by two tropical seagrass species as measured in situ. Mar Biol 137: $755-761$

Sharkey T, Berry JA (1985) Carbon isotope fractionation of algae as influenced by an inducible $\mathrm{CO}_{2}$ concentrating mechanism. In: Lucas WJ, Berry JA (eds) Inorganic carbon uptake by aquatic photosynthetic organisms. American Society of Plant Physiology, Rockville, MD, p 389-402

Uku J, Beer S, Bjork M (2005) Buffer sensitivity of photosynthetic carbon utilisation in eight tropical seagrasses. Mar Biol 147:1085-1090

Submitted: December 23, 2008; Accepted: May 5, 2009

Proofs received from author(s): July 6, 2009 